\title{
〔序説〕外科侵襲における病態生理
}

\author{
田中武彦, 小川嘉誉* \\ 城 戸 良 弘。”富克宏* \\ 大阪大学医学部栄秦学教空 \\ 大阪大学医学部第 2 外科学教空
}

\section{F 说}

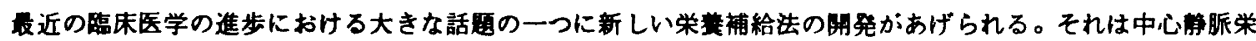

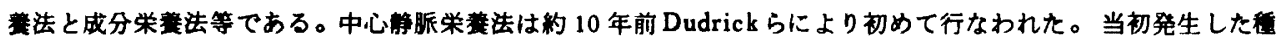
管の合併应や障害は新しい莱材の開発，管理の工夫，踰液組成の改善等により克服され，現在では非常に広く用 いられるように至っており，その恩恵ははかりしれないものがある。成分栄秦法もまた長い歴史的経過の後宇宙 食としても用いられ，また策床上の応用もしだいに広がりつつある。これらの方法は自発的な食物の経口摄取の 不可能な場合やあるいは臨床上の理由によりそれを避けたほうが望ましい揚合などに広く用いられている。

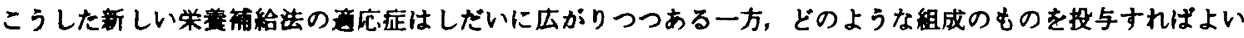
かという栔題かさらに重要なものとして考えられ始めている。患者の病態に対応したそれぞれの固有の組成が求

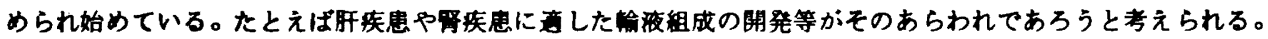

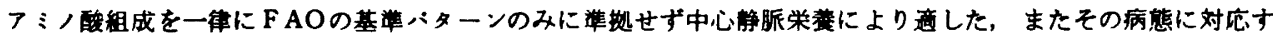
る組成が考えられ蛞めているわけである。

賽の問題とともに昷の問題もまた解決すべき課題であろう。栄養負荷は生命維持に不可欠であるが，一方，生 体にとっては負荷された栄賚秦を処理しなければならない点から大きな負担でもあり, “Nutritional Stress”

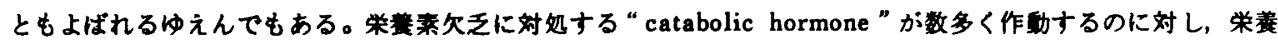
負荷に対しわずかにインシュリンのみが“anabolic hormone”として中心的役割を果たしているという生体の

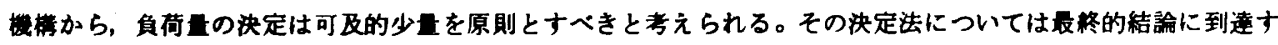

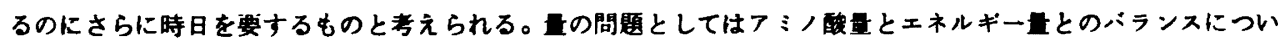
ても，窒素出納とェネルギー出納をともにみたす来件とすべきか，あるいはいずれかを传先してもよいかでは， 投与量に大きな隔りが生じてくる。

これら課题の総合的な判断は，結局，患者の栄卷状態の評価により決定されるべきであろうと考えられる。栄

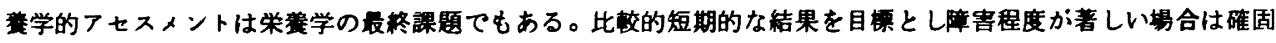
とした明確な評価は容易になしうる。しかし長期的な見通しのもとにいわゆる “ marginal state ”を判定するこ とは必ずしも容易ではない。基碦的な研究の望まれるゆえんであろう。

中心㬹脈栄咅の通応が非常に厇かりをみせている現状において，依然として最も多いのは術前・術後の管理を

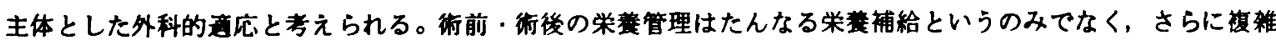
な状況下における管理である。それは良好な年件下における手術であってもその手術の大きさに応じて，生体の 代碀に大きな変化が生じ，したがっていわゆる外科的侵婓を避けることができないからである。本稿においては

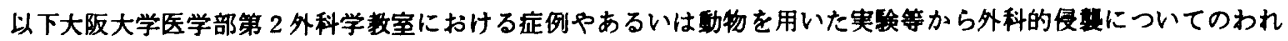
われの考え方を述べていきたい。

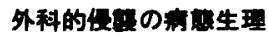

外科的侵襲時の病態代辢についての研究はクラスコーのSir D. P. Cuthbertsonに負らところがきわめて大き い。彼は 1920 年代の後半より本研究に取り組み受御後の生体に大きな代謝の変化かみられ，その経過は “ ebb” 
および“flow”の 2 相に分けられることを報じた。受鹪後の生体の反応について，その後Moore は代謝系およ び内分泌系の变動等についての考察から，4 相に分類し鹪害期 (adrenergic corticoid phase)，変换期 (Corticoid withdrawal phase), 筋力回復期 (muscle strength phase), 脂肪回得期 (fat gain phase) に分けた。 いずれにせよ受得後の代謝変化を異化期と同化期に分けることについては軌を一にしている。“ebb phase”は

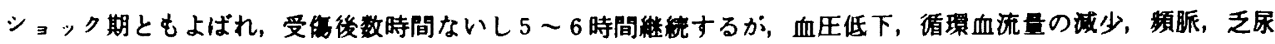
等のいわゆるンッック状態でありこれに对応するカテュラミン優位の状態でもある。この時期が過ぎ去ると “flow phase”となり副骨皮筫ホルモンをはじめとするいわゆる catabolic hormoneの传位状態となり,エネル

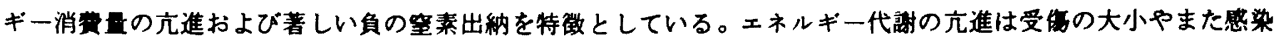

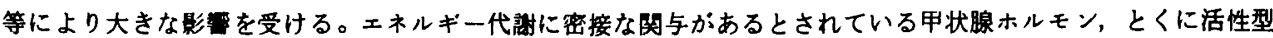

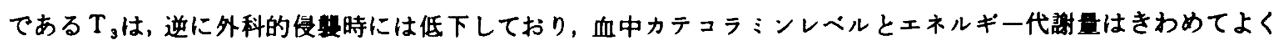

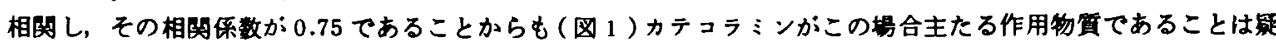

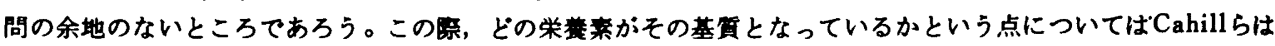

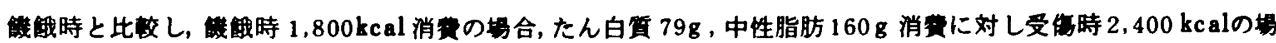
合，たん白質 $250 \mathrm{~g}$ ，脂肪 $160 \mathrm{~g}$ の消費となるとして，盯藏脂肪の消费は意外にも堌進するよりはむしろ成少の槙 向を示し，体たん白の消耗か受得後增大することを報告している。阪大第 2 外科の症例においても高カロリー崳

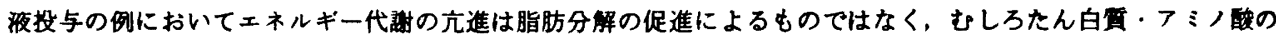
異化の六進していることを認めている。このようなたん白筫異化の元進は結果的には等素出納の著しい負をもた らしているものと考えられる。このような代䅎の变化に対し非常に異なった三つの䑳の組成が考えられている。 第1の方法はインシュリン,タルュースを投与し，たん白留の異化を抑制し可能な限り㮒莱出納の負を少なくす る。第 2 の方法は，たん白質の異化に見合うだけのフミ，酸混合を投与し、エネルギー出納はともかく空莱出納 のみを可能な限り負となるのを防ぐといら方法，第3はエネルギー出納，空素出納両者を可能な限り負にするこ とを防ぐためにクルコースとアミ,酸混合液をバランスよく投与ナる方法, という以上の 3 方法であり, 現在で は第了の取も常諳的な方法が用いられている。

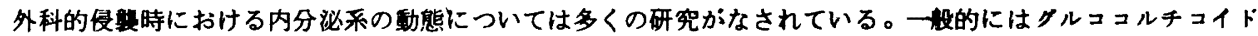

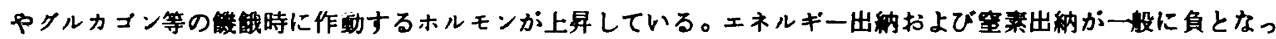
ていること，および代謝が機諓時に比孉的類似していることから，上記の内分泌系の反応は一応首肯しうるもの

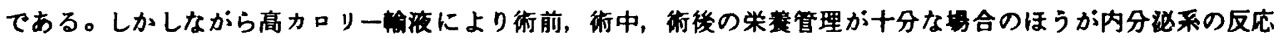
かより著明であることが実祭の患者の例で明らかとなった。この煩向はとくにカテュラミンについて著しい(困

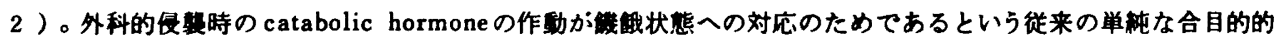

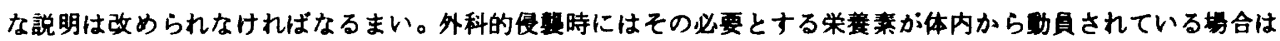
もちろんいうまでもなく体外から供給されている場合でも, 代郡がcatabolic な流れの方向であることは注目す べきであることであろう。

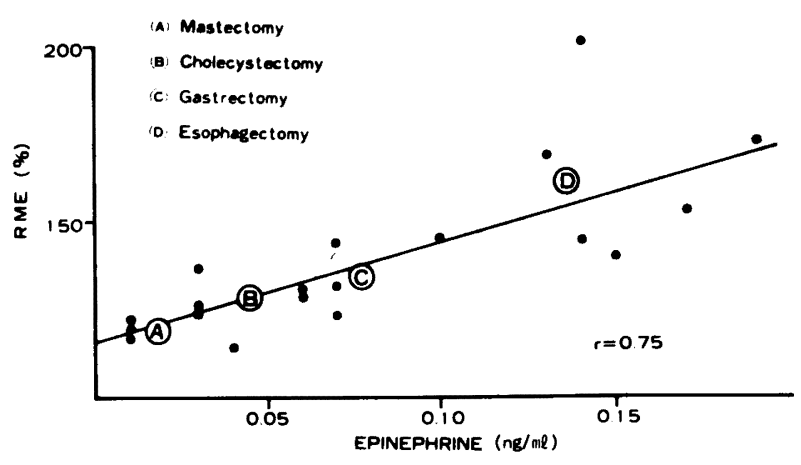

园 1 
〔序説〕外科侵貿における病態生理

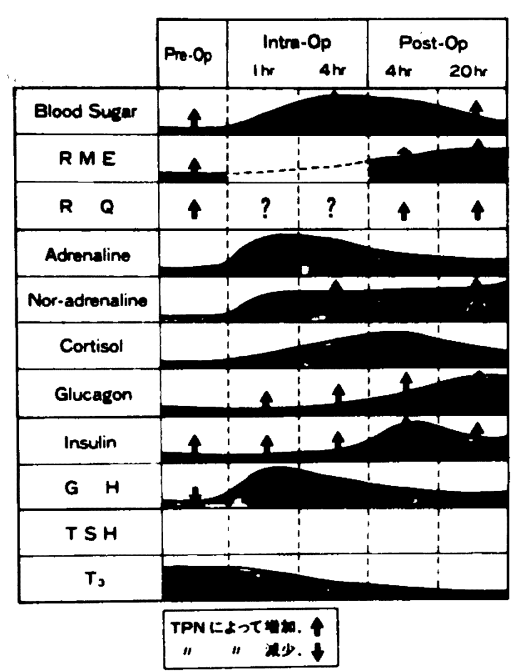

図 2

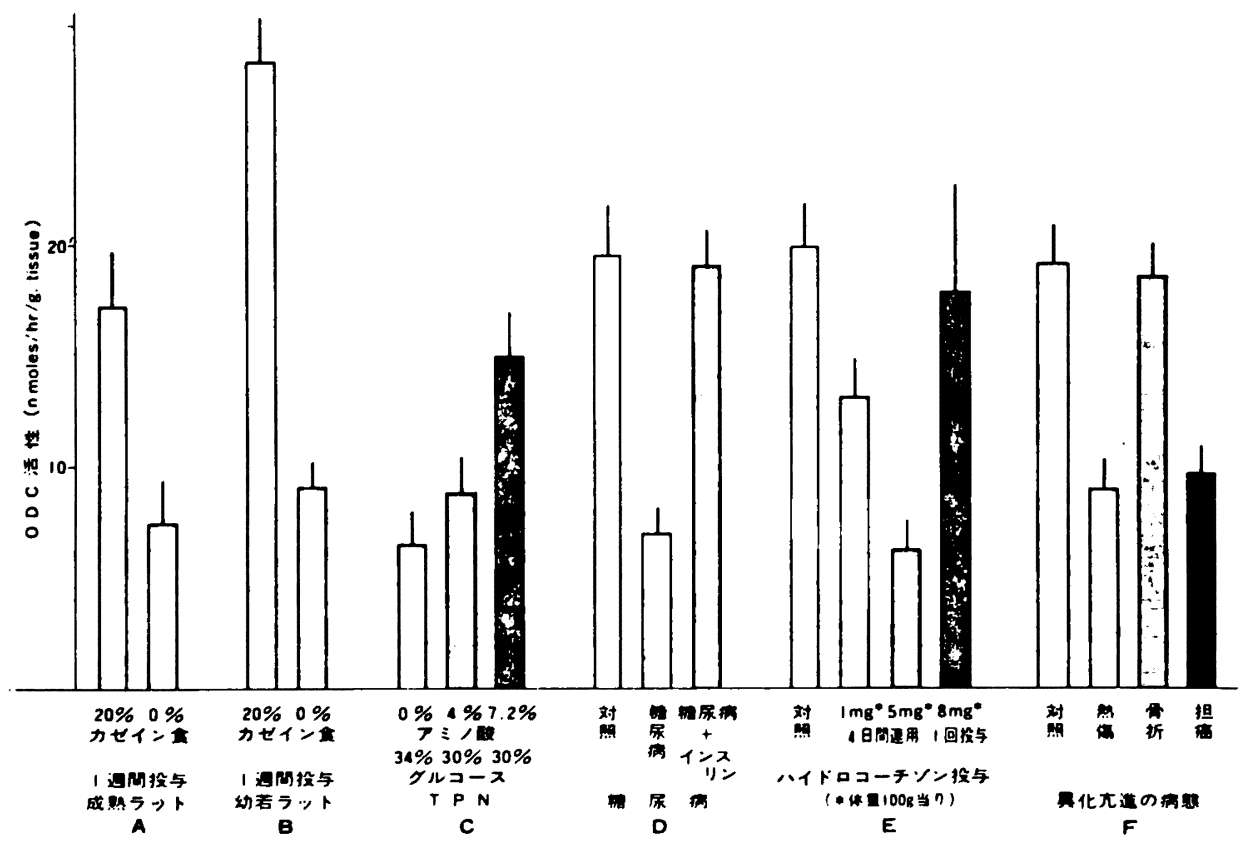

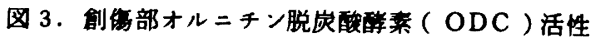




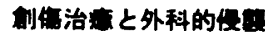

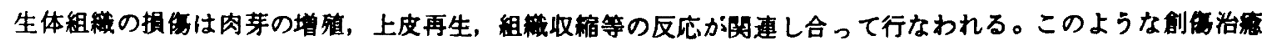

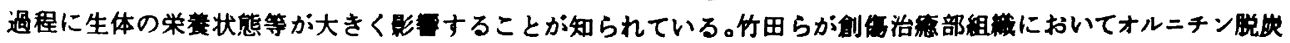

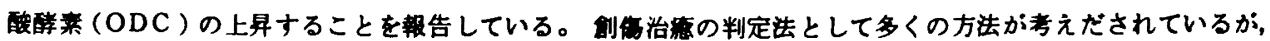
いずれも繁雅な方法ばかりでることから，私どもは創得部のODC活性上开に注目し本醇菜活性測定が創的治

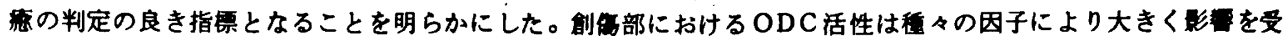

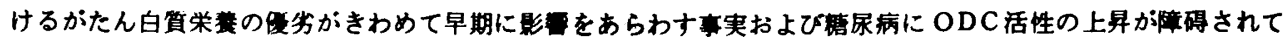

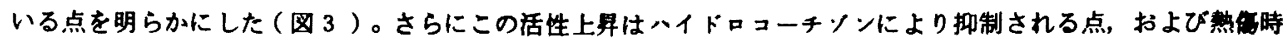

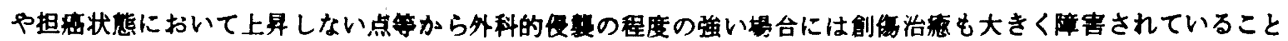
が明らかとなった。

\section{路}

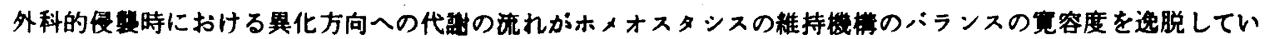
るか不かという点か今後の高カロリ一夜を考えるうえに大きな問題点であろう。内分必系の動態のみからみれ

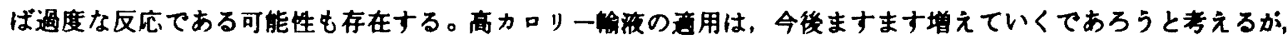

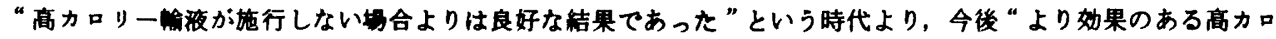
リー偷を求める”という時代へと移り進むであろうことが考えられよう。 